\title{
Emission and Noise Characteristics of a Diesel Engine Fuelled with Diesel-Chicken Oil Biodiesel Blends
}

\author{
Abid Ali Khaskheli \\ Department of Mechanical Engineering \\ Quaid-e-Awam University of \\ Engineering, Science and Technology \\ Nawabshah, Pakistan \\ abidali_lifeskill@yahoo.com
}

\author{
Haris Jawad Arain \\ Department of Energy \& Environmental \\ Engineering, Quaid-e-Awam University \\ of Engineering, Science and Technology \\ Nawabshah, Pakistan \\ harisjawad@quest.edu.pk
}

\author{
Imdad Ali Memon \\ Department of Mechanical Engineering \\ Quaid-e-Awam University of \\ Engineering, Science and Technology \\ Nawabshah, Pakistan \\ engineerimdad@yahoo.com
}

\author{
Umair Ahmed Rajput \\ Department of Mechanical Engineering \\ Quaid-e-Awam University of Engineering, Science and \\ Technology \\ Nawabshah, Pakistan \\ engineer.umair@quest.edu.pk
}

\author{
Muhammad Junaid Ahsan \\ Department of Energy \& Environmental Engineering \\ Quaid-e-Awam University of Engineering, Science and \\ Technology \\ Nawabshah, Pakistan \\ mjunaidahsan@quest.edu.pk
}

\begin{abstract}
Biodiesel is a renewable, safe, environmentally friendly, and significant source of energy which produces a lesser amount of greenhouse effect gasses. The biodiesel source is local chicken frying oil, synthesized by the trans-esterification process. In this research, the Particulate Matter (PM) exhaust gas emissions and sound emissions are examined. Emissions such as PM (PM1.0, PM2.5, PM7.0, and PM10), nitric oxides (i.e. NO and $\left.\mathrm{NO}_{2}\right), \mathrm{CO}, \mathrm{CO}_{2}$, and noise were investigated at variable loads with constant engine speed. Fuel samples, i.e. pure diesel (D100) and $20 \%$ Biodiesel (B20) and 30\% Biodiesel (B30) blends were tested. Conventional diesel was found to emit more particulate and sound emissions, while B30 had lower emissions than B20 and conventional diesel. The lowest average values regarding exhaust gas emissions was $0.00690 \mathrm{ppm}$ for PM1.0, 7.44ppm for $\mathrm{NO}_{2}$, and $190.727 \mathrm{ppm}$ for $\mathrm{CO}$, presented in B30. However, emissions from the engine decreased with increase in the blending ratio of biodiesel. Furthermore, the lowest average value of $\mathrm{CO}_{2}$ was found in $B 30$ and was about $1.457 \%$.
\end{abstract} engine

Keywords-chicken frying oil; B20; B30; emissions; noise;

\section{INTRODUCTION}

Vehicles are almost entirely fuelled by internal combustion engines which burn fossil fuels such as Liquefied Petroleum Gas (LPG) and oil. But global fossil fuel reserves are limited and in the not so distant future will become depleted. The most prominent alternative to the classic internal combustion engine is undoubtedly Electric Vehicles (EVs). In recent years, interest in electric cars has been growing, and over the past decade, EV production has increased dramatically by $1500 \%$ [1]. Nowadays, millions of people suffer from severe illnesses and even die from causes such as cancer, respiratory diseases, cardiovascular diseases, vision loss, etc. which are affiliated with hazardous exhaust gases produced by fossil fuel engines. Besides, many countries, which have signed the Kyoto Protocol, fail to comply with their obligation to lower their level of greenhouse gases. The addition of nanoparticles to diesel is one of the most effective ways of converting diesel to a cleaner source of energy [2]. Biodiesel is considered as an improved, renewable, and non-hazardous fuel substitute. It is obtained from animal fats or vegetable oils, and it is commonly manufactured by the trans-esterification process. Biodiesel has more oxygen content than oil diesel [3-7]. Cooking waste is an alternative option for the production of economically and environmentally friendly biodiesel. While waste cooking oil has high free fatty acids and cannot be used directly into the engine, but it can convert into biodiesel by trans-esterification. The blends of biodiesel with various sources of oil affect more the performance and the emissions of the engine. Authors in [810] investigated bio-diesel from waste edible oil, coconut oil, and castor oil obtained by trans-esterification in blends with conventional diesel fuel.

Methanol, methyl esters, ethanol, and deposit oils formed from biomass are known as biofuels [11]. Trans-esterification is the process in which alcohol and esters (triglyceride) react together and form methyl esters (biodiesel) and glycerol. It is the most common method to make biodiesel from edible oils, waste food oil, animal fats, and waste eating greases (yellow grease). Those oils are considered possible candidates to complete the vacuum created by the reduction of conventional diesel fuels [12]. Waste edible oils produce excellent results, are environmentally friendly, have reduced cost, and decreased 
exhaust gas emissions. Biodiesel with blends has successful performance and reduces $\mathrm{PM}, \mathrm{CO}_{2}$, and $\mathrm{CO}$ emissions as compared to diesel fuel [13-15].

In this study, wasted frying chicken oil was collected from the local city of Nawabshah, Pakistan. That oil was converted into biodiesel by trans-esterification [23]. The current research investigated the emissions of a diesel engine using different oil blends and conventional diesel. $\mathrm{PM}, \mathrm{NO}_{\mathrm{x}}, \mathrm{CO}_{2}, \mathrm{CO}$ and sound emissions were measured for the performance comparison of biodiesel and conventional diesel fuel.

\section{EXPERIMENTAL METHOD}

The working principle of the compression-ignition (CI) diesel engine consists of four strokes with a single, horizontal type, water-cooled cylinder used for changing performance parameters. The model name/serial number of the testbed diesel engine was DWE-6/10-JS-DV. The testbed, fully equipped with instruments such as thermometer, dynamometer, tachometer, flow meter, and flue gas analyser, is shown in Figure 1.

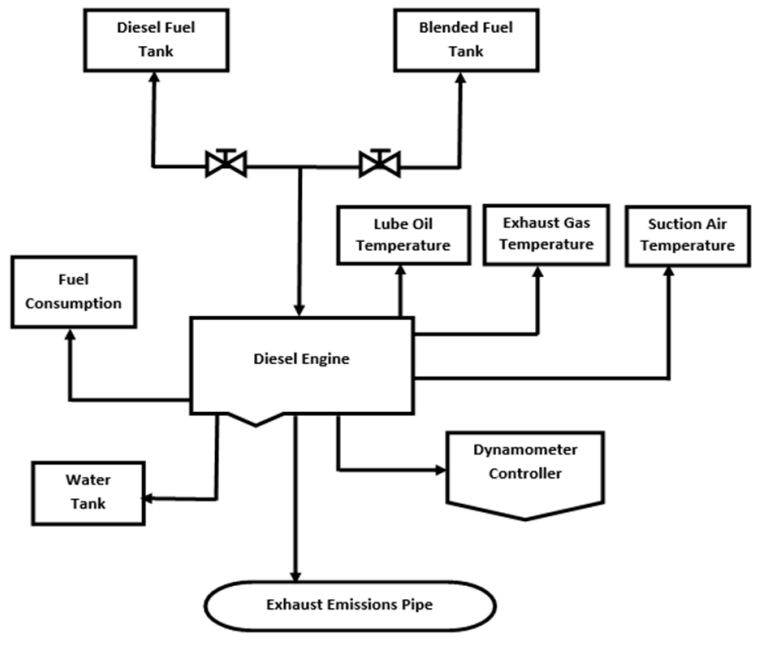

Fig. 1. Diesel engine test bed diagram

Two fuel tanks were added to the diesel motor with ground and normal pipelines. The fuel tanks were linked with normal lines, and the fuel supply could be controlled with two different valves. One fuel tank was filled with diesel fuel and the other with biodiesel. In this work, three fuel types were tested: D100 (diesel 100\%), B20 (biodiesel 20\% + diesel 80\%) and B30 (biodiesel 30\% + diesel 70\%). All samples were investigated for PM and exhaust gas emissions on varying load under constant motor speed. The specifications of the diesel engine are shown in Table I [23].

\section{A. Fuel Parameters}

Fuel parameters can affect engine emissions. Biodiesel produced specific almost identical parameters when it was blended in diesel fuel in different ratios. In this research, blends were arranged by volume percentage. The settings of all samples on ASTM standards are shown in Table II [23].
TABLE I. ENGINE SPECIFICATIONS

\begin{tabular}{|c|c|}
\hline Number of cylinders & 1 \\
\hline Cooling system & Water-cooled \\
\hline Type & Horizontal \\
\hline Piston size (bore) & $80 \mathrm{~mm}$ \\
\hline Displacement of the piston (strokes) & $95 \mathrm{~mm}(477 \mathrm{cc})$ \\
\hline Compression ratio & $23: 1$ \\
\hline Starting method & Manual \\
\hline Output/rotational speed & $8.5 \mathrm{PS} / 2200 \mathrm{rpm}(\max )$ \\
\hline
\end{tabular}

TABLE II. FUEL PARAMETERS OF ALLA SAMPLES

\begin{tabular}{|c|c|c|c|c|c|c|}
\hline Physical property & Unit & D100 & B20 & B30 & $\begin{array}{c}\text { ASTM } \\
\text { standard }\end{array}$ & $\begin{array}{c}\text { Testing } \\
\text { limits }\end{array}$ \\
\hline Total acid number & $\mathrm{mgKOH} / \mathrm{g}$ & 0.24 & 0.27 & 0.28 & $\mathrm{D}-664$ & $0.80 \mathrm{max}$ \\
\hline $\begin{array}{c}\text { Specific gravity at } \\
15.6^{0} \mathrm{C}\end{array}$ & - & 0.83 & 0.85 & 0.84 & $\mathrm{D}-891$ & $0.8-0.9$ \\
\hline $\begin{array}{c}\text { Kinematic viscosity } \\
\text { at } 40^{\circ} \mathrm{C}\end{array}$ & $\mathrm{mm}^{2} / \mathrm{s}$ & 1.98 & 2.78 & 2.43 & $\mathrm{D}-445$ & $1.9-6.0$ \\
\hline Density at $40^{\circ} \mathrm{C}$ & $\mathrm{g} / \mathrm{cm}^{3}$ & 0.85 & 0.86 & 0.86 & $\mathrm{D}-1298$ & $0.86-0.90$ \\
\hline $\begin{array}{c}\text { Cetane-index } \\
\text { calculated) }\end{array}$ & - & 56.9 & 54.4 & 53.5 & $\mathrm{D}-976$ & $47 \mathrm{~min}$ \\
\hline Flash point & ${ }^{0} \mathrm{C}$ & 103 & 123 & 115 & $\mathrm{D}-93$ & $130 \mathrm{~min}$ \\
\hline Pour point & ${ }^{0} \mathrm{C}$ & 0 & +1.5 & +1.8 & $\mathrm{D}-97$ & $-15-+5^{\circ} \mathrm{C}$ \\
\hline Calorific value & $\mathrm{MJ} / \mathrm{kg}$ & 44.8 & 43.2 & 43.8 & $\mathrm{D}-240$ & $37.5-45$ \\
\hline Oxygen content & $\mathrm{wt} \%$ & 0 & 2.53 & 3.71 & - & - \\
\hline
\end{tabular}

\section{B. PM and Exhaust Gas Measurements}

The PM emissions depend on load, speed, and fuel characteristics of the engine. In this study, PM emissions of four distinct particle sizes, PM1.0, PM2.5, PM7.0, and PM10 along with exhaust gas emissions $\left(\mathrm{CO}_{2}, \mathrm{CO}, \mathrm{NO}\right.$, and $\mathrm{NO}_{2}$ were measured from the diesel engine. A PM hand held device was used for particulate emissions and a Flue Gas Analyser model no. Test 350-XL was used for exhaust gas emissions (Figure 2). The measurements of the Gas Analyser are shown in Table III.
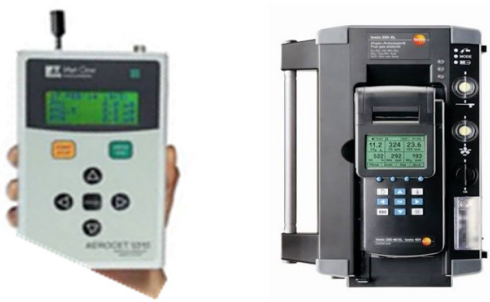

Fig. 2. Hand held PM measuring device and gas analyzer

TABLE III. GAS ANALYZER MEASUREMENTS

\begin{tabular}{|c|c|c|c|}
\hline Gas & Measuring range & Unit & Accuracy \\
\hline $\mathrm{NO}$ & 0 to +300 & $\mathrm{ppm}$ & $\pm 2 \mathrm{ppm}(0$ to $+39.9 \mathrm{ppm})$ \\
\hline $\mathrm{NO}_{2}$ & 0 to +500 & $\mathrm{ppm}$ & $\pm 5 \mathrm{ppm}(0$ to $+99.9 \mathrm{ppm})$ \\
\hline $\mathrm{CO}_{2}$ & 0 to +50 & Vol. $\%$ & $\pm 0.3 \mathrm{Vol} . \%+1 \%$ of $\mathrm{mv}(0$ to $25 \mathrm{Vol} . \%)$ \\
\hline $\mathrm{CO}$ & 0 to 500 & $\mathrm{ppm}$ & $\begin{array}{c} \pm 5 \% \text { of } \mathrm{mv}(+40 \text { to }+500 \mathrm{ppm}) \\
\pm 2 \mathrm{ppm}(0 \text { to }+39.9 \mathrm{ppm})\end{array}$ \\
\hline
\end{tabular}

\section{Engine Noise Level Measurements}

The noise level was determined by a sound pressure level meter (Figure 3). The three different fuels were measured for noise level on varying load conditions at a constant speed. All fuel samples were measured for varying load on the engine from 0 to $20 \mathrm{~N} . \mathrm{m}$. Three different directions, front, left, and 
back, were selected for measuring. The microphone was set up at $1 \mathrm{~m}$ away from the engine cylinder at the above mentioned three locations. The specifications of the microphone are given in Table IV.

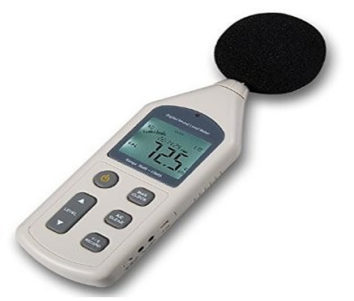

Fig. 3. Held hand noise level meter

TABLE IV. HAND HELD NOISE METER SPECIFICATIONS

\begin{tabular}{|c|c|}
\hline Type & Electric condenser microphone \\
\hline Range of dB level & $35 \mathrm{~dB}$ to $150 \mathrm{~dB}$ \\
\hline Determination & $0.1 \mathrm{~dB}$ \\
\hline Accuracy & $\pm 1.5 \mathrm{~dB}$ \\
\hline Microphone diameter & $1 / 2 "$ \\
\hline Dynamic range & $55 \mathrm{~dB}$ \\
\hline
\end{tabular}

\section{RESULTS AND DISCUSSION}

\section{A. Engine Emissions}

The engine emissions depend on operating conditions, engine type, fuel, lubricating oil, and the control of the emission systems. In general, the exhaust contains PM, nitric oxides, $\mathrm{CO}$, and $\mathrm{CO}_{2}$. PM, and $\mathrm{CO}$ emissions decreased when the ratio of biodiesel blended in the diesel increased [16-18]. The average emissions values are shown in Table V.

TABLE V. AVERAGE ENGINE EMISSIONS OF ALL SAMPLES

\begin{tabular}{|c|c|c|c|c|c|}
\hline Fuel & $\begin{array}{c}\text { PM1.0 } \\
\text { (ppm) }\end{array}$ & $\begin{array}{c}\text { NO } \\
(\mathbf{p p m})\end{array}$ & $\begin{array}{c}\mathbf{N O}_{2} \\
(\mathbf{p p m})\end{array}$ & $\begin{array}{c}\mathbf{C O}_{2} \\
\mathbf{( \% )}\end{array}$ & $\begin{array}{c}\text { CO } \\
(\mathbf{p p m})\end{array}$ \\
\hline $\mathrm{D} 100$ & 0.0269 & 65.909 & 11.845 & 1.832 & 361.272 \\
\hline $\mathrm{B} 20$ & 0.0123 & 73.090 & 15.318 & 1.542 & 287.727 \\
\hline $\mathrm{B} 30$ & 0.00690 & 53 & 7.44 & 1.457 & 190.727 \\
\hline
\end{tabular}

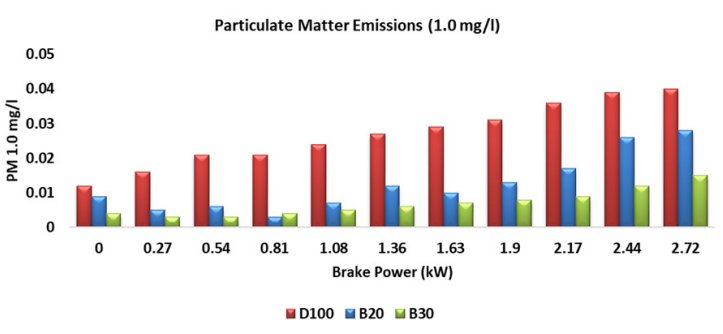

Fig. 4. Comparison results for PM1.0 emissions

\section{B. Particulate Matter (PM) Emissions}

$\mathrm{PM}$ is an air-suspended mix of active and liquid particles of varying size, shape, surface region, number and compound arrangement, solvency, and source [19]. Diesel fuel is a major PM source. Both B20 and B30 samples had less PM emissions than pure diesel, with B30 having the least emissions. The PM emission results are shown in Figures 4-6.

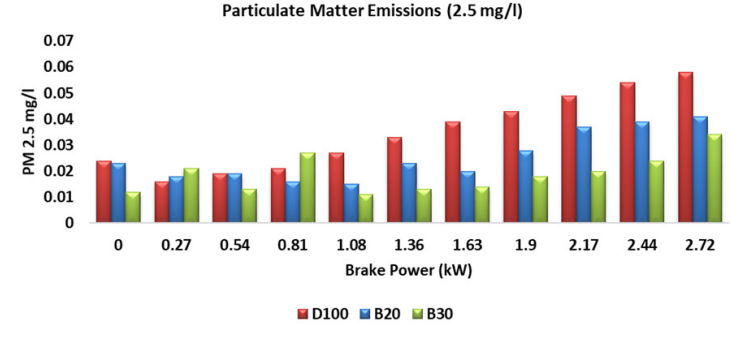

Fig. 5. Comparison results for PM2.5 emissions

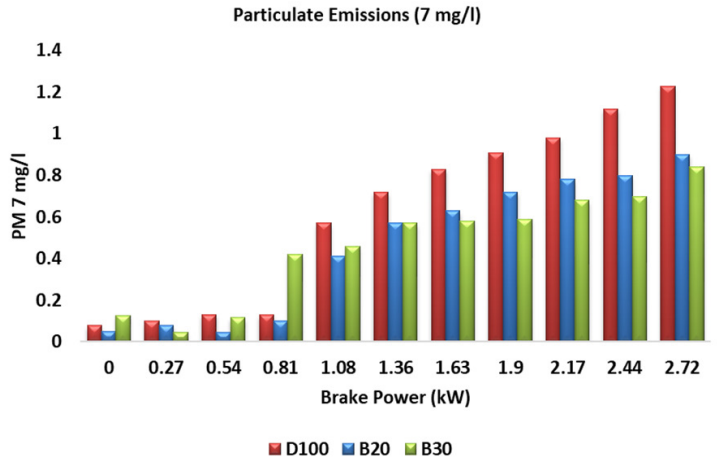

Fig. 6. Comparison results for PM7.0 emissions

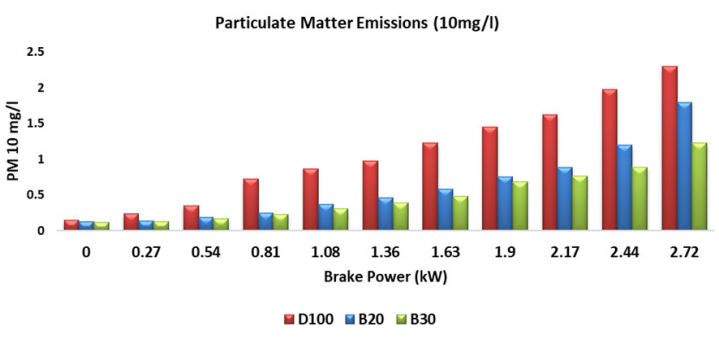

Fig. 7. Comparison results for PM10 emissions

\section{Nitric Oxides $\left(N O_{x}\right)$ Emissions}

Biodiesel has a shorter deferred start, $\mathrm{NO}_{\mathrm{x}}$ outflow reduction, and a high cetane profile. In any case, high burning temperatures came to the ignition because of more upper ignition timing and more extended staying period and $\mathrm{NO}_{\mathrm{x}}$ discharges were increased. Biodiesel diminishes the $\mathrm{NO}_{\mathrm{x}}$ discharges by enhancing fuel properties [20].

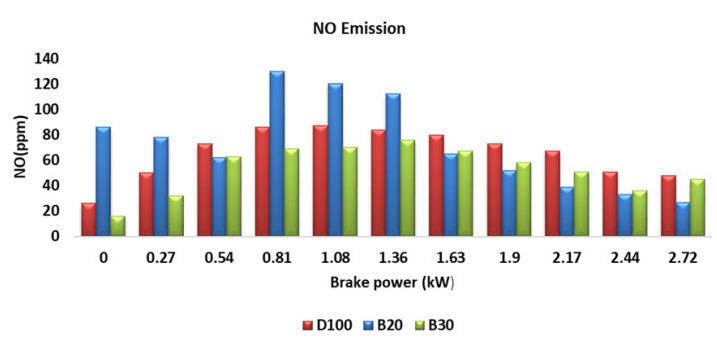

Fig. 8. Comparison results for $\mathrm{NO}$ emissions

Consequently, $\mathrm{NO}$ emissions reduced by increasing loads. In this comparative study, $\mathrm{NO}_{\mathrm{x}}$ emissions increased in $\mathrm{B} 20$ as 
compared to D100 at different loading conditions of the engine. The B30 had lower $\mathrm{NO}_{\mathrm{x}}$ emissions due to the decreasing exhaust gas temperature with quick combustion from the engine [23]. The $\mathrm{NO}_{\mathrm{x}}$ emissions of $\mathrm{B} 30$ increased at middle engine load, while they reduced with increasing load. The results of $\mathrm{NO}_{\mathrm{x}}$ emissions are shown in Figures 8-9.

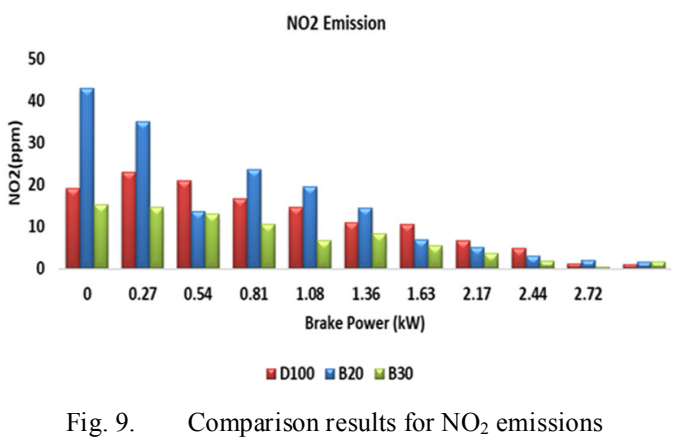

\section{Carbon Dioxide $\left(\mathrm{CO}_{2}\right)$ Emissions}

$\mathrm{CO}_{2}$ is a colorless and non-combustion gas released when fuels with carbon content burn entirely. Consequently, $\mathrm{CO}_{2}$ is a significant parameter in engine exhaust emissions. The $\mathrm{CO}_{2}$ emissions increase when engine's speed and loading increase. The exhaust emissions of $\mathrm{CO}_{2}$ were determined for varying loads at a constant engine speed [21]. In this study, the percentage of $\mathrm{CO}_{2}$ emissions decreased when the ratio of blends in biodiesel increased. Therefore, the average value of $\mathrm{CO}_{2}$ emissions from $\mathrm{B} 30$ was $0.373 \%$. The $\mathrm{CO}_{2}$ emissions for all samples are shown in Figure 10.

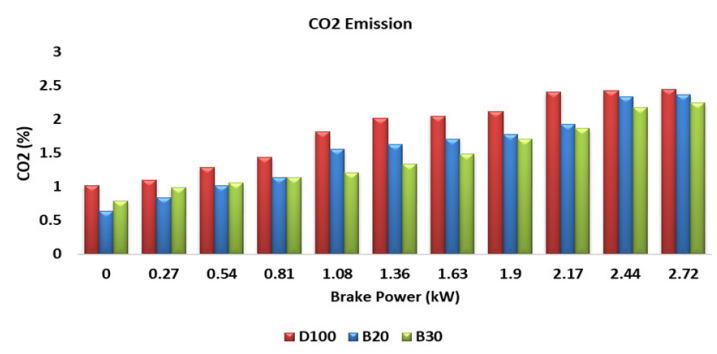

Fig. 10. Comparison results for $\mathrm{CO}_{2}$ emissions

\section{E. Carbon Monoxide (CO) Emissions}

$\mathrm{CO}$ emissions depend on the speed of the engine. They occur when the combustion is insufficient, and therefore, fuel cannot oxidize [25]. Oxygen content in ethanol is high, which allows lower $\mathrm{CO}$ emissions and increased burning quality [26]. $\mathrm{CO}$ production results from oxidation of fuel, including carbon and hydrogen, with oxygen. In this work, three different fuels were studied for $\mathrm{CO}$ emissions on variable load and at a constant speed. CO emissions reduced when the blending ratio of biodiesel in diesel increased. The comparison results of carbon monoxide emissions are shown in Figure 11.

\section{F. Noise Characteristics}

Usually noise level decrement is accompanied with biodiesel practice. Noise is fundamentally influenced by motor speed because of upward and descending cylinder development in the motor chamber [22]. Diesel fuel has a lesser amount of aromatic compounds than biodiesel. The aromatic compounds increase the ignition delay by decreasing the noise level. In this research, the noise levels were measured for different loading conditions of the engine. Therefore, three locations (i.e. front, left, and back) were designated for noise level study. All corresponding positions were $1 \mathrm{~m}$ away from the piston head cylinder. The noise level depends on the load and the blending ratios of biodiesel [24]. The noise level decreased slightly after increasing the middle brake load of the engine. The results showed that diesel produced higher noise level than B20 and B30. The B30 sample exhibited the least noise level due to its improved oxygen content. The results are shown in Figures 1214.

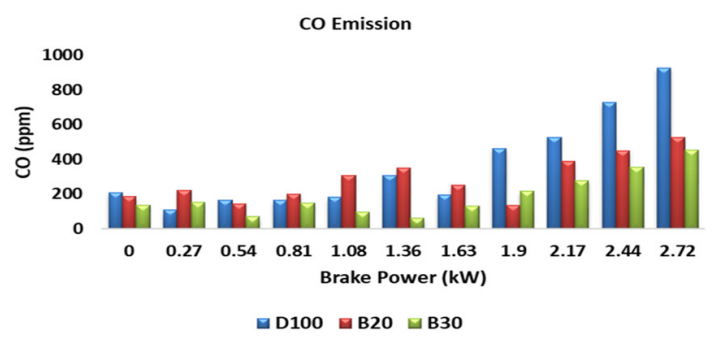

Fig. 11. Comparison results for $\mathrm{CO}$ emissions

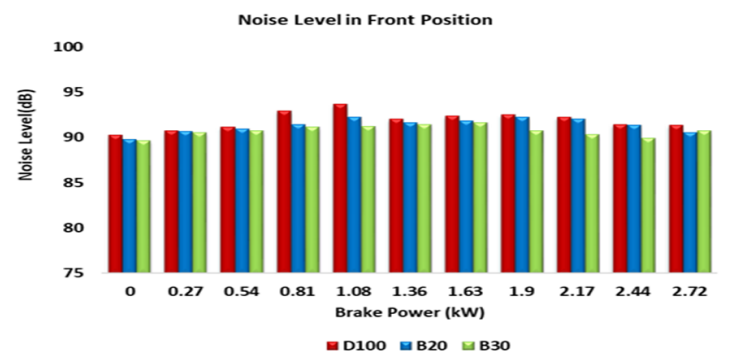

Fig. 12. Comparison results of engine's noise level (front position)

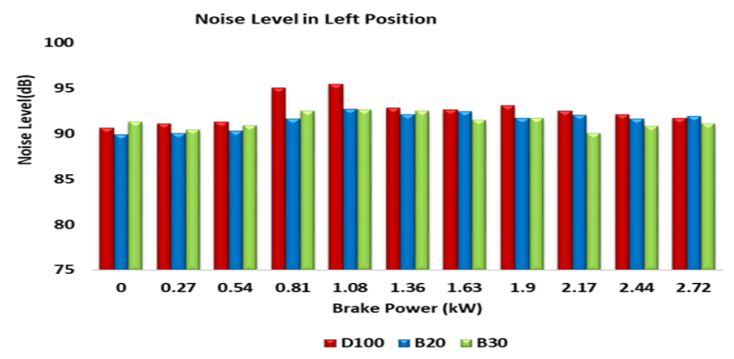

Fig. 13. Comparison results of engine's noise level (left position)

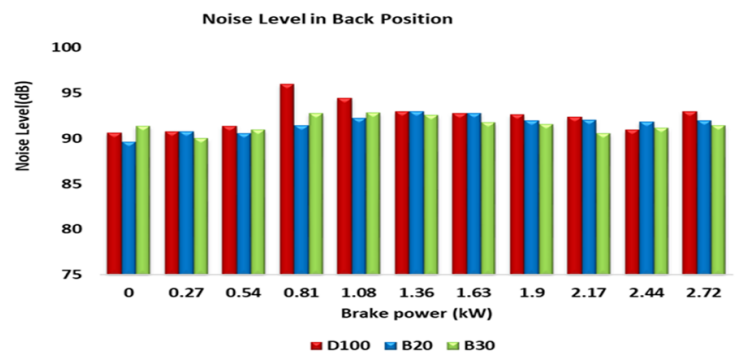

Fig. 14. Comparison results of engine's noise level (back position) 


\section{CONCLUSIONS}

PM1.0 was the higher emitted PM component. B20 produced less PM emissions than D100, while B30 produced even less on variable loadings. Nitric oxide emissions increased for B20 as compared to D100 at different loading conditions, while for B30 they were less than diesel and B20 due to the lower exhaust gas temperature and quick combustion. $\mathrm{CO}_{2}$ emissions increased when the speed and loading conditions of the engine increased. Lower average value of $\mathrm{CO}_{2}$ emissions in the engine was observed when using B30. CO emissions moreover deceased with increasing blending ratio of biodiesel due to the high oxygen content of the blends. The noise level was reduced when the $\mathrm{B} 30$ was used due to the improved combustion process because the addition of biodiesel provided more oxygen atoms in the combustion chamber.

\section{ACKNOWLEDGMENT}

This research work was conducted in the Thermodynamics Engineering Laboratory at the Department of Mechanical Engineering, Quaid-e-Awam University of Engineering, Science \& Technology Nawabshah, Pakistan.

\section{REFERENCES}

[1] U. Agbulut, H. Bakir, "The investigation on economic and ecological impacts of tendency to electric vehicles instead of internal combustion engines", Duzce Universitesi Bilim ve Teknoloji Dergisi, Vol. 7, No. 1, pp. $25-36,2019$

[2] U. Agbulut, S. Saridemir, "A general view to converting fossil fuels to cleaner energy source by adding nanoparticles", International Journal of Ambient Energy, available at: www.tandfonline.com/doi/ abs/10.1080/01430750.2018.1563822?journalCode=taen20 2019

[3] S. Sadaf, J. Iqbal, I. Ullah, H. N. Bhatti, S. Nouren, H. U. Rehman, J. Nisar, M. Iqbal, "Biodiesel production from waste cooking oil: an efficient technique to convert waste into biodiesel", Sustainable Cities and Society, Vol. 41, pp. 220-226, 2018

[4] Y. Liu, Q. Tu, G. Knothe, M. Lu, "Direct transesterification of spent coffee grounds for biodiesel production", Fuel, Vol. 199, pp. 157-161, 2017

[5] K. A. Abed, A. K. E. Morsi, M. M. Sayed, A. A. E. Shaib, M. S. Gad, "Effect of waste cooking-oil biodiesel on performance and exhaust emissions of a diesel engine", Egyptian Journal of Petroleum, Vol. 27, No. 4, pp. 985-989, 2019

[6] J. M. Jung, S. R. Lee, J. Lee, T. Lee, D. C. W. Tsang, E. E. Kwon, "Biodiesel synthesis using chicken manure biochar and waste cooking oil”, Bioresource Technology, Vol. 244, pp. 810-815, 2017

[7] G. Knothe, L. F. Razon, "Biodiesel fuels", Progress in Energy and Combustion Science, Vol. 58, pp. 36-59, 2017

[8] P. Zareh, A. A. Zare, B. Ghobadian, "Comparative assessment of performance and emission characteristics of castor, coconut and waste cooking based biodiesel as fuel in a diesel engine", Energy, Vol. 139, pp. 883-894, 2017

[9] H. Liu, X. Ma, B. Li, L. Chen, Z. Wang, J. Wang, "Combustion and emission characteristics of a direct injection diesel engine fueled with biodiesel and PODE/biodiesel fuel blends", Fuel, Vol. 209, pp. 62-68, 2017

[10] T. Sukjit, V. Punsuvon, "Process optimization of crude palm oil biodiesel production by response surface methodology", European International Journal of Science and Technology, Vol. 2, No. 7, pp. 4956,2017

[11] K. Manivannan, P. Aggarwal, V. Devabhaktuni, A. Kumar, D. Nims, P. Bhattacharya, "Particulate matter characterization by gray level cooccurrence matrix based support vector machines", Journal of Hazardous Materials, Vol. 223-224, pp. 94-103, 2012
[12] T. Wiesenthal, B. Schade, G. Leduc, L. Govaerts, L. Pelkmans, P. Georgopoulos, P. Christidis, "Biofuel support policies in Europe: Lessons learnt for the long way ahead", Renewable and Sustainable Energy Reviews, Vol. 13, No. 4, pp. 789-800, 2009

[13] M. M. Hasan, M. M. Rahman, "Performance and emission characteristics of biodiesel-diesel blend and environmental and economic impacts of biodiesel production: A review", Renewable and Sustainable Energy Reviews, Vol. 74, pp. 938-948, 2017

[14] J. Xue, "Combustion characteristics, engine performances and emissions of waste edible oil biodiesel in diesel engine", Renewable and Sustainable Energy Reviews, Vol. 23, pp. 350-365, 2013

[15] I. A. Resitoglu, K. Altinisik, A. Keskin, "The pollutant emissions from diesel-engine vehicles and exhaust aftertreatment systems", Clean Technologies and Environmental Policy, Vol. 17, No. 1, pp. 15-27, 2015

[16] X. Shen, J. Shi, X. Cao, X. Zhang, W. Zhang, H. Wu, Z. Yao, "Realworld exhaust emissions and fuel consumption for diesel vehicles fueled by waste cooking oil biodiesel blends", Atmospheric Environment, Vol. 191, pp. 249-257, 2018

[17] A. K. Agarwal, K. Rajamanoharan, "Experimental investigations of performance and emissions of Karanja oil and its blends in a single cylinder agricultural diesel engine", Applied Energy, Vol. 86, No. 1, pp. 106-112, 2009

[18] O. Can, "Combustion characteristics, performance and exhaust emissions of a diesel engine fueled with a waste cooking oil biodiesel mixture", Energy Conversion and Management, Vol. 87, pp. 676-686, 2014

[19] P. Geng, H. Mao, Y. Zhang, L. Wei, K. You, J. Ju, T. Chen, "Combustion characteristics and NOx emissions of a waste cooking oil biodiesel blend in a marine auxiliary diesel engine", Applied Thermal Engineering, Vol. 115, pp. 947-954, 2017

[20] K. Manivannan, P. Aggarwal, V. Devabhaktuni, A. Kumar, D. Nims, P. Bhattacharya, "Particulate matter characterization by gray level cooccurrence matrix based support vector machines", Journal of Hazardous Materials, Vol. 223-224, pp. 94-103, 2012

[21] S. M. Palash, M. A. Kalam, H. H. Masjuki, B. M. Masum, I. M. R. Fattah, M. Mofijur, "Impacts of biodiesel combustion on NOx emissions and their reduction approaches", Renewable and Sustainable Energy Reviews, Vol. 23, pp. 473-490, 2013

[22] E. Uludamar, E. Tosun, K. Aydin, "Experimental and regression analysis of noise and vibration of a compression ignition engine fuelled with various biodiesels", Fuel, Vol. 177, pp. 326-333, 2016

[23] A. A. Khaskheli, G. D. Walasai, A. S. Jamali, Q. B. Jamali, Z. A. Siyal, A. Mengal, "Performance evaluation of locally-produced waste cooking oil biodiesel with conventional diesel fuel", Engineering, Technology \& Applied Science Research, Vol. 8, No. 6, pp. 3521-3524, 2018

[24] S. Saridemir, U. Agbulut, "Combustion, performance, vibration and noise characteristics of cottonseed methyl ester-diesel blends fuelled engine", Biofuels, available at: www.tandfonline.com/doi/ abs/10.1080/17597269.2019.1667658?journalCode=tbfu20, 2019

[25] U. Agbulut, S. Saridemir, S. Albayrak, "Experimental investigation of combustion, performance and emission characteristics of a diesel engine fuelled with diesel-biodiesel-alcohol blends", Journal of the Brazilian Society of Mechanical Sciences and Engineering, Vol. 41, Article ID 389,2019

[26] U. Agbulut, S. Saridemir, G. Durucan, "The impacts of ethanol-gasoline blended fuels on the pollutant emissions and performance of a sparkignition engine: an empirical study", International Journal of Analytical, Experimental and Finite Element Analysis, Vol. 5, No. 4, pp. 50-59, 2018 